\title{
- BUILDING FROM SCRATCH: New Cities, Privatized Urbanism and the Spatial Restructuring of Johannesburg after Apartheid
}

CLAIRE W. HERBERT AND MARTIN J. MURRAY

\begin{abstract}
By the start of the twenty-first century, the once dominant historical downtown core of Johannesburg had lost its privileged status as the center of business and commercial activities, the metropolitan landscape having been restructured into an assemblage of sprawling, rival edge cities. Real estate developers have recently unveiled ambitious plans to build two completely new cities from scratch: Waterfall City and Lanseria Airport City (formerly called Cradle City) are master-planned, holistically designed 'satellite cities' built on vacant land. While incorporating features found in earlier city-building efforts, these two new self-contained, privately-managed cities operate outside the administrative reach of public authority and thus exemplify the global trend toward privatized urbanism. Waterfall City, located on land that has been owned by the same extended family for nearly 100 years, is spearheaded by a single corporate entity. Lanseria Airport City/Cradle City is a planned 'aerotropolis' surrounding the existing Lanseria airport at the northwest corner of the Johannesburg metropole. These two new private cities differ from earlier large-scale urban projects because everything from basic infrastructure (including utilities, sewerage, and the installation and maintenance of roadways), landscaping, security services, the regulation of common spaces, and selling and branding the city are firmly in the hands of private profit-making corporate entities and outside the mandate of public authorities.
\end{abstract}

\section{Introduction}

Johannesburg after apartheid has come to resemble a vast, distended megalopolis without obvious or fixed boundaries-a sprawling, spatially fragmented and increasingly polynucleated conurbation that urban theorists have variously referred to as the 'city turned inside out' (Soja, 1992; 1996), 'exopolis' (Soja, 1992), 'postmetropolis' (Soja, 2000), the 'polycentric metropolis' (Hall and Pain, 2006), the 'dispersed metropolis' (Gordon and Richardson, 1996), 'sprawl city' (Bullard et al., 2000) and the '100 mile city' (Sudjic, 1993). ${ }^{1}$ As the once-strong attachment to its historic downtown urban core loosened over the past 30 years, the greater Johannesburg metropolitan region exploded into a galaxy of more or less equally fungible satellite cities, business nodal points and commercial entertainment clusters spread across vast geographical distances and loosely connected by an extensive network of highways (Beavon, 1997; Bremner, 1998; Beavon, 2004; Murray, 2008; 2011: xii, 29). In a full reversal of modernistinspired city building, these spatially driven processes of 'peripheral urbanization', or the 'urbanization of suburbia' (Soja, 1996: 345; 2000), have produced a radical inversion of the conventional relationship between high-density urban core and lowdensity suburban periphery. Central-place functions (corporate headquarters, office buildings, upscale shopping and retail commerce, and world-class entertainment sites) are increasingly spread out among rival 'edge cities'-the colloquial name given to dispersed, and disconnected, nodal cluster points located on the urban periphery (Garreau, 1991; Beauregard, 1995; Teaford, 1997).

1 Information to support the analysis for this article is derived from numerous on-site visits to both Lanseria Airport City/Cradle City and Waterfall City, and from interviews with key corporate property owners, urban planners and real estate developers conducted during June/July 2011 and June 2012 in Johannesburg. All those interviewed (and listed in the Appendix) have given the authors permission to refer to them by name. 
In the greater Johannesburg metropolitan region, the accumulated power of real estate capital has simply dwarfed the regulatory impulses of municipal planning authorities seeking to reverse long-term patterns of automobile-dependent horizontal sprawl, environmentally destructive land speculation and the seemingly endless replication of similar building typologies such as securitized office parks, townhouse cluster developments, gated residential estates and themed entertainment destinations (Bloom, 2006). These sequestered sites are typically sealed off from the surrounding urban landscape by a crusty perimeter of high walls, formidable gates and security checkpoints. The proliferation of these privatized (post-public) enclaves has led to the gross devaluation of urban public space as a powerful social, civic and political ideal in post-apartheid South Africa (Bremner, 1998; 2002b; 2005; Lipman and Harris, 1999; Czeglédy, 2003; Dirsuweit and Schattauer, 2004; Murray, 2008; 2011: 19; 2013).

This privately driven, laissez-faire approach to city building reached new heights with the unveiling of visionary plans to construct two new satellite citiesWaterfall City and Cradle City-on the peri-urban periphery. ${ }^{2}$ With their ambitious scale and holistic design, these proposed cities have brought entirely new meaning to entrepreneurial urbanism in the greater Johannesburg metropolitan region. Located about halfway between the Johannesburg central city and Pretoria, these masterplanned and privately managed enclaves promise to provide a wide variety of mixed-use facilities in a single, self-enclosed location. ${ }^{3}$ Hoping to gain swift regulatory approval for their proposed construction, the real estate developers behind these two megaprojects claim that their plans for building dense, compact and sustainable cities can contribute to the laudable goal of reversing the trend toward unplanned suburban sprawl with its automobile dependence and negative environmental impact. ${ }^{4}$ By rhetorically positioning themselves as champions of cutting-edge sustainable urbanism and proponents of a more compact urban form incorporating mixed land use, higher residential densities and closer proximity between home and work opportunities, the developers hoped to disarm their critics and silence skeptics. ${ }^{5}$

Located about 15 miles $(24 \mathrm{~km})$ from the historic downtown core, the satellite city of Sandton-often referred to as the richest square mile on the African continentis universally acknowledged as the premier financial and corporate showcase location in the greater Johannesburg metropolitan region. If Sandton conforms to the idealtypical expression of a classical edge city, then Waterfall City and Lanseria Airport City (LAC)/Cradle City signal the opening gambit of a completely novel approach to corporate-sponsored city building. Incorporated as a separate metropolitan entity in 1969, Sandton grew incrementally over time; retrofitted office blocks and the addition of tall skyscrapers, luxury hotels and up-to-date business convention centers have produced a highly concentrated built environment that is hemmed in by existing residential suburbs. In contrast, Waterfall City and LAC/Cradle City are master-planned 'instant cities', built entirely from scratch on huge expanses of uninhabited land, with large-scale private property owners playing a prominent and decisive regulatory role in the administration and management of municipal functions once under the exclusive domain of public authorities, such as major infrastructure installation, utility provision and ensuring safety and security. ${ }^{6}$ Rather than performing as monofunctional or singleuse centers dependent upon automobile commuting, these self-sufficient megaprojects promise to become central places in their own right, with strong local networks,

Cradle City is the original name of this large-scale real estate project, first unveiled in 2008. In 2010, a new group of property developers took charge of the project, renaming their new vision Lanseria Airport City (LAC). Interviews with Parke (11 July 2011), Seward (13 July 2011), van Brakel (8 July 2011) and Aitken (8 July 2011). Interviews with Parke (11 July 2011) and Seward (13 July 2011).

See Amari Properties, Cradle City Master Plan (submitted to the City of Johannesburg Development Planning and Urban Management Department, Development Planning \& Facilitation, 27 June 2008).

Interviews with Holman (8 July 2011), van Brakel (8 and 13 July 2011); Vos (12 July 2011) and Parke (11 July 2011). 
connections and all the amenities and services associated with urban life (Varnelis, 2005: 184).

As a general rule, research and writing on large-scale city-building projects (known as 'megaprojects') has focused a great deal of attention on the role of publicprivate partnerships in sponsoring and facilitating strategic interventions in urban regeneration (see, inter alia, Dick and Rimmer, 1998; Swyngedouw et al., 2002; Altshuler and Luberoff, 2003; Bezmez, 2008; Diaz Orueta and Fainstein, 2008; Fainstein, 2008; Lehrer and Laidley, 2008; Taşan-Kok, 2010; Kokx, 2011; Paling, 2012; Doucet, 2013). While this scholarly literature has greatly enhanced our understanding of the often contentious balance between public authority and private entrepreneurialism in largescale city-building projects, what has been largely overlooked is the incipient global trend toward master-planned, holistically designed private cities in which the participation of municipal authorities as active partners, or even detached facilitators, has been reduced to a minimum. Critical examination of the single-handed role of corporate enterprise as the driving force behind these megaprojects has remained in its infancy (for some exceptions, see Borsdorf et al., 2007; Kanna, 2011; Shatkin, 2011; Bunnell et al., 2012; Datta, 2012; Hogan et al., 2012; Murphy and Hogan, 2012). ${ }^{7}$ Exploring the visions, goals and values accompanying the evolution of Waterfall City and LAC/Cradle City can assist us in shedding more light on the changing dynamics of city building on a global scale, where real estate developers around the world appear more interested in constructing entirely new cities from scratch than retrofitting the built environment of the existing urban fabric (Douglass and Huang, 2007; Shatkin, 2011; Datta, 2012; Paling, 2012). Equally important, a more detailed look at these privatized enclaves enables us to address pressing questions for twenty-first century urbanism related to environmental sustainability, social exclusion and the spatial fragmentation of cities (Kim, 2010; Douglass, 2010; Thompson, 2013).

At present, Waterfall City and LAC/Cradle City are unfinished city-building projects, albeit at wholly different stages of completion. Construction at Waterfall City is well under way. The installation of basic infrastructure, roadways and the construction of the security entryways and perimeter walls for all eleven precincts are nearly complete. The private hospital and satellite health clinics, retirement villages, upscale residential estates and affordable housing units are fully operational. By contrast, the original Cradle City project experienced some difficulties getting beyond the initial planning stages and into full production. Financing and corporate investment proceeded at a snail's pace during the initial stages. Under the umbrella of Amari Holdings/Forum Properties, this megaproject existed as little more than a collection of boosterist projections, color-coded site plans and a bulldozed yet barren landscape. In 2010, the Lanseria Airport City Development Corporation incorporated the original Cradle City scheme, reinvigorating the fledgling project by introducing an infusion of fresh capital, new ideas and a more sophisticated management team. What these two places will eventually become remains an open question. Yet even as partially real and partially imaginary places, they offer clues as to where large-scale city-building efforts might be heading and what corporate real estate builders imagine the 'future city' of Johannesburg to be (Bremner, 2005).

\section{The post-suburban metropolitan landscape: master-planned estates and private enclaves}

City building in Johannesburg has increasingly been left to the competitive anarchy of unrestrained market forces, and the resulting patterns of growth and development reflect the dominance of real estate capitalism as the driving force behind the

7 In recent years, corporate giants such as Cisco Systems, Siemens and IBM have unveiled ambitious plans to provide comprehensive packages of integrated infrastructure for large-scale, privately driven city-building projects. 
shaping and reshaping of the built environment. In contrast to the radial-concentric model of urban evolution, in which an increase in density within the central city takes place in tandem with the extensive horizontal expansion of the peri-urban fringe, the spatial pattern of metropolitan Johannesburg is an uneven patchwork of multiple high-density nodal points and low-density suburban sprawl (Murray, 2011: 29-32). The metamorphosis of the post-suburban periphery into what Kazys Varnelis (2005: 183) has termed 'cluster-based network urbanism' marks the consolidation of a new phase of metropolitan transformation at the start of the twenty-first century.

In the Johannesburg metropolitan region, this pattern is illustrated by the steady growth of such relatively independent satellite cities as Sandton, Randburg and Rosebank-each with their own raison d'être and diverse socio-economic specializations-which has led to the dissipation of socio-economic power away from the historic urban core and its spatial dispersal across these fragmented edge cities, which vary in size and socio-economic influence (Rogerson, 2003; Mabin, 2007). By offering new high-wage employment opportunities, luxury housing and upscale shopping, which in the past were only available closer to the historic downtown area, these edge cities have become exemplars of what urban theorists have referred to variously as 'exopolises' (Soja, 1992), 'technoburbs' (Fishman, 1987), 'boomburbs' (Lang and Lefurgy, 2007) and 'edgeless cities' (Lang, 2003). These post-suburban 'outer cities' (Hansen and Winther, 2007) were never subordinate appendages of the historic downtown urban core, but rather evolved into mixed-use entities in their own right. They are rapidly urbanizing landscapes that have attracted increased concentrations of capital investment to a variety of activities, including light industrial, small-scale manufacturing and securitized office parks. These edge cities are almost seamlessly integrated with high-end residential estates and sites of leisure and entertainment, such as multi-use casino complexes (Montecasino, Emperors Palace), upscale shopping malls (Sandton City, Hyde Park Mall, Fourways Mall and Pine Slopes), gated residential communities and security villages (Dainfern, Kyalami Estate), exclusive golf estates (Lone Hill, Blue Valley, Centurion Country and Residential Estate, Waterkloof Golf Estate, Jackal Creek and Leeukop), and luxurious getaway conference facilities located in tranquil country settings. The well-manicured image of socio-economic vitality of these post-suburban outer cities dovetails with their real increase in significance as economic powerhouses and growth machines at the edge of the metropolitan region (Bremner, 2002a; 2005; Mabin, 2007; Chipkin, 2008; Murray, 2011; 2013).

Over the past several decades, an entirely new outer ring of concentrated business-commercial centers has proliferated along the northern perimeter of the Johannesburg metropolis. Located much further afield than the original edge cities of Sandton, Randburg and Rosebank, these new nodal points include Fourways/Midrand, Illovo, Sunninghill, Bryanston, and-even further afield-Lanseria, Weltevreden Park, Randpark Ridge and Kempton Park (Rogerson, 2003). As a market-driven response to middle-class demand for the amenities of city life combined with the tranquil setting of a safe and secure country lifestyle, these new satellite cities exemplify the drive for escapist urbanism. They are ever-changing works-in-progress that give new substance and meaning to evolving patterns of contemporary peripheral urbanization. These newest incarnations of peripheral urbanization are connected to one another by almost uninterrupted ribbons of haphazard development: corridors of low-rise office buildings, warehousing and distribution facilities, industrial parks, manufacturing sites and nondescript strip malls. Their poorly planned landscapes-driven primarily by large-scale property developers and real estate agencies with little interference or oversight by public authorities-provide visible clues for understanding the implications of city building in the new South Africa, and how emerging urban enclaves characterized by glamour and luxury are linked to global flows of capital, information, commodities and people (Murray, 2011: 107-8, 119-20). 


\section{Private cities-in-the-making: why LAC/Cradle City and Waterfall City represent a new kind of master-planned, fast-track urbanism}

As entrepreneurial modes of municipal governance have replaced mainstream managerialist approaches to public administration, Johannesburg has experienced a dramatic transformation in the relationship between power and space. ${ }^{8}$ Fast-track urban enclaves-which are master-planned, holistically designed and privately ownedaspire to administrative autonomy, seeking an extra-territorial status that enables property owners to assume the bureaucratic responsibilities and regulatory functions once reserved for exclusive control by municipal authorities (Murray, 2011: xxv, 250-51). No longer content with the modernist model of functional specialization that led to a radical separation between high-density corporate business centers and sprawling, low-density residential suburbs, city builders have looked for innovative ways to seamlessly integrate corporate, commercial, residential and recreational uses of space in a single, self-contained and self-sustaining location. While New Urbanism has looked backward to imagine neo-traditional towns that celebrate small-scale localism and face-to-face community, what might be called radical re-urbanism has set its sights on anticipating a more demanding and uncertain future, where integration into the globalized world of corporate enterprise requires a great deal of agility and flexibility (Dunham-Jones, 2000; Fishman, 2008). Large-scale, master-planned and holistically designed urban enclaves represent real-life laboratories for new experiments in faux urbanity. This kind of re-urbanism involves rethinking basic ideas about the role of private enterprise in the provision and maintenance of infrastructure and the role of large-scale property owners in city management and governance (Goldberger, 1996; Graham and Marvin, 2001; Easterling, 2007a; 2007b).

The scale, scope and ambition of Waterfall City and LAC/Cradle City are unprecedented in South African urban history. While they appear to share many features and exhibit continuities with previous real estate development projects on the metropolitan periphery, these new satellite cities are fundamentally different owing to the core features they share. First, Waterfall City and LAC/Cradle City have been built entirely from scratch on vacant land. In contrast to the model of 'organic urbanism', where the built environment evolves piecemeal and incrementally over time, these two instant cities are exemplars of fast-track urbanism, that is, they are constructed for immediate occupation and use without any intermediate steps. This process of unveiling the new city all at once produces a dreamscape of literally starting de novo, where everything is up to date and cutting-edge. Secondly, Waterfall City and LAC/ Cradle City are large-scale, master-planned satellite cities where functionally specialized parts are seamlessly tied together into an integrated whole. Everything from building typologies, architectural styles, and physical specifications (size, volume, setbacks and height requirements) are structured in accordance with a predetermined holistic design. Unlike the idealized 'unplanned city' that evolves spontaneously in response to changing needs and interests, the spatial layout and physical design of these two cities follow strict guidelines and building regulations, leaving nothing to chance. There is no room for spontaneity, local autonomy or infrastructural retrofitting. Thirdly, Waterfall City and LAC/Cradle City are self-sufficient cities-within-cities. These mixed-use developments include a full complement of 'cradle-to-grave' urban amenities-from schools, to office complexes and shopping districts, to residential estates and burial sites. Fourthly, Waterfall City and LAC/Cradle City are entirely private cities, where the public realm has virtually disappeared. The real estate developers who designed these two urban enclaves envision a top-down regulatory regime where private, profit-making companies own and manage everything from hospitals to

8 For key interventions into the entrepreneurial urbanism debate, see Harvey (1989); Hall and Hubbard (1996); Jessop (1997); MacLeod (2002) and Ward (2003). 


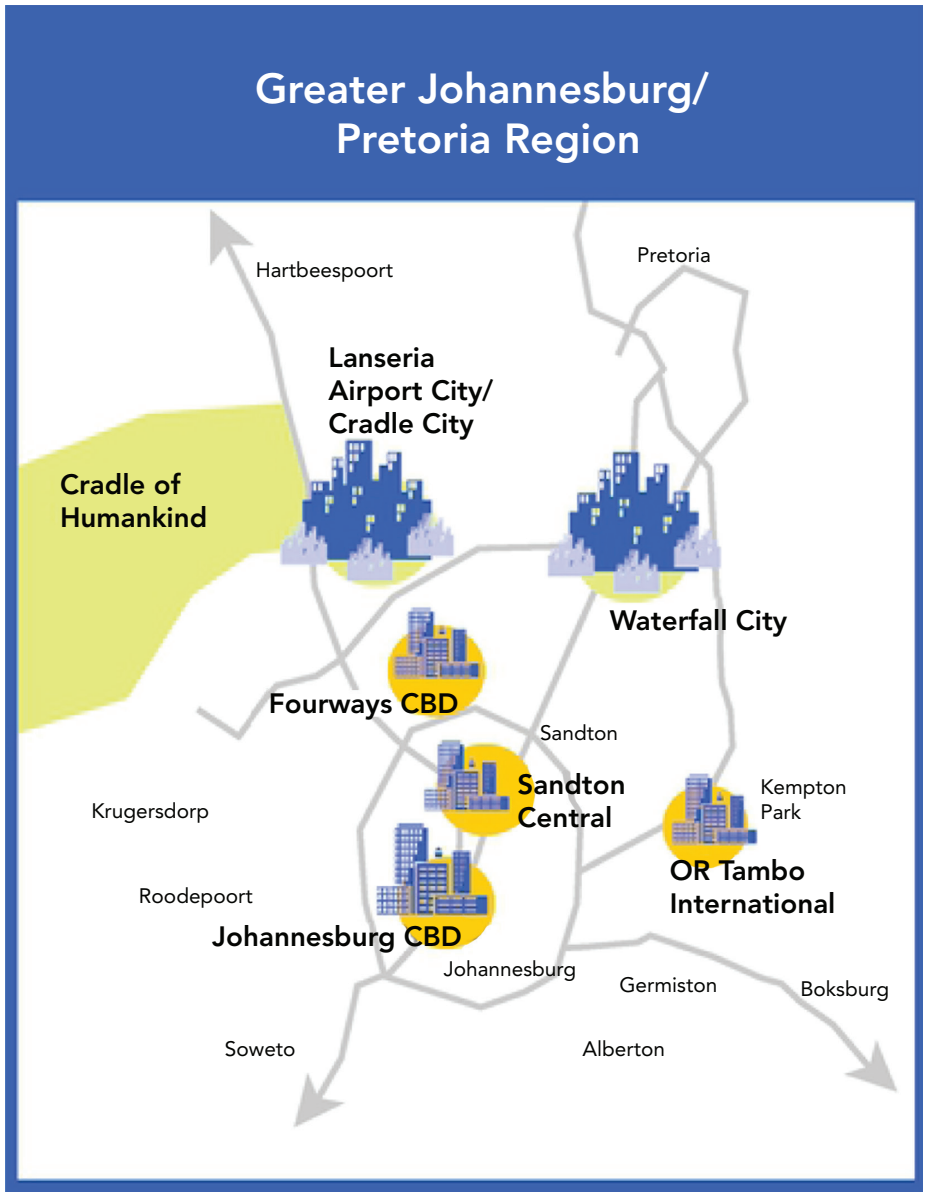

FIGURE 1 Development sites for Waterfall City and Lanseria Airport City/Cradle City (map produced on behalf of the authors by Stephanie McClintick)

schools and gravesites, and from landscaping and road maintenance to safety and security. Finally, Waterfall City and LAC/Cradle City are thoroughly embedded in an ideology and discourse of hyper-modernity. The 'live-work-play' atmosphere combined with the paranoid fixation on personal safety and security dovetail with promises of leisurely lifestyle living, comfortable eco-friendly surroundings and energy efficient, sustainable infrastructural systems.

\section{Waterfall City: cradle-to-grave city}

Straddling the major M1 highway between the Buccleuch interchange and Allandale Road off-ramp about halfway between Johannesburg and Pretoria, Waterfall City has effectively closed the gap between Midrand and the upscale residential suburbs of Woodmead, Sunninghill and Buccleuch (see Figure 1). Located on one of the two remaining large parcels of undeveloped land in Midrand, Waterfall City is a stunning exemplar of the global shift toward 'privatized planning', or what Gavin Shatkin (2008: 388) calls the 'transfer of power over and responsibility for the visioning of urban futures' from public officials and into the hands of large-scale real estate developers (see Goldberger, 1996; Pírez, 2002). Waterfall City offers a full range of life-cycle 


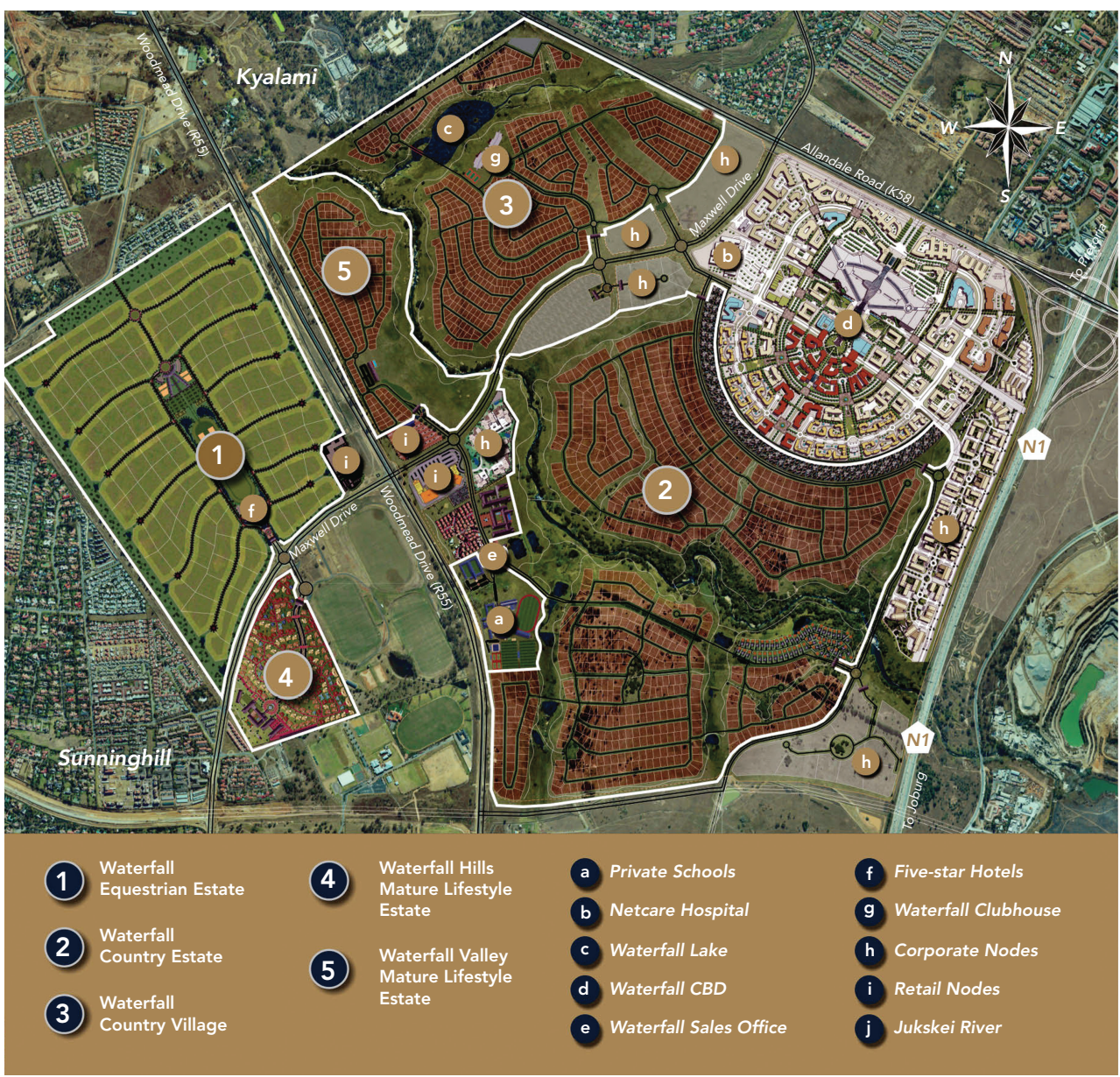

FIG URE 2 Waterfall City Urban Design Plan (source: Century Property Developments, n.d., Waterfall country lifestyle estate and village, promotional brochure, page 2, available at http://www.century.co.za/email/270wce.pdf)

amenities available in few other places. ${ }^{9}$ By bringing together all the essential features that characterize a fully functioning metropolis within its boundaries, this megaproject is an all-encompassing city, dreamed up and fabricated by private real estate developers, planners and urban design specialists. Waterfall City represents the cutting edge of the trend toward privatized urbanism that has captured the imagination of city builders in Johannesburg. Construction is well under way but the project is expected to take close to a decade before fully complete. This upscale development-located on an expansive 5,400 acre $(2,200$ hectare) site and projected to cost an astounding R45 billion (US $\$ 5.5$ billion)-promises to take the concept of mixed-use property development to new heights in South Africa (EPROP, 2009b). ${ }^{10}$ Billed as the "next Sandton' (ibid.), Waterfall City has been called 'the biggest property development in South African history' (Fife and Bhengu, 2006), its residential population expected in time to exceed 100,000 (Cox, 2006b). estates, advertising brochure, available at www.century.co.za (accessed 10 May 2014). 
The comprehensive, holistic design of Waterfall City enables it to stand out as a fully functioning city-within-a-city rather than merely an elaborate variant of a gated residential estate or a securitized corporate office park, and is set to become a benchmark in cutting-edge, cosmopolitan urban design (Fife, 2008; EPROP, 2009b). Waterfall City will have its own town square, five-star hotels, central-city apartments, enclosed corporate office complexes equal to about two-thirds of the Sandton CBD, industrial warehousing space equal to half that in Midrand, a multi-use transport hub, a service yard for the Gautrain high-speed rail system and 1.6 million square feet (about $150,000 \mathrm{~m}^{2}$ ) of retail shopping. Embracing the 'live-work-play' concept, Waterfall City consists of a variegated assemblage of gated residential estates for affluent homebuyers, lifestyle centers, conference and exhibition facilities, the largest artificial lake in Gauteng province, bicycle and hiking trails, a full-service gymnasium, as well as other leisure and entertainment sites (see Figure 2) (Fife and Bhengu, 2006; EPROP, 2009b; Cox, 2010). Promoted as a true cradle-to-grave city, the Waterfall City project includes comprehensive plans for everything necessary for each step of life, from several prestigious international schools catering to the children of overseas business executives to state-of-the-art health care facilities (including private clinics and a large multi-facility for-profit hospital) and two prestigious retirement villages, to what is expected to be Africa's largest cemetery with 500,000 plots. Ambitious future planning also involves using the existing hospital facilities as the foundation for establishing a fully accredited private medical school-the first of its kind in South Africa (Fife and Bhengu, 2006). ${ }^{11}$

As an exemplar of upscale enclave-style development, this megaproject promises to become-in less than a decade-a key business and commercial growth point with transportation tentacles stretching in all directions (EPROP, 2009b). ${ }^{12}$ As a prime location for both corporate office parks and upscale residential accommodation, Waterfall City expects to draw business tenants away from the nearby Sandton CBD. The real estate developers at Waterfall City have promised to provide many upscale amenities not available in Sandton, including a heliport close to the planned CBD, convenient parking facilities and improved traffic circulation. In addition, unlike the overcrowded and densely packed spatial landscape of Sandton, Waterfall City offers spacious residential precincts, including country-style estates with sizeable lots, equestrian stables and common-use polo grounds. ${ }^{13}$ Waterfall City is located in close proximity to three of the new high-speed Gautrain rail stations at Marlboro, Midrand and AECI. It also provides easy access to both Pretoria and downtown Johannesburg via the main north-south (N1) highway system, through which 120,000 cars pass in each direction every day. ${ }^{14}$

Two large-scale real estate development companies-Atterbury Property Group and Century Property Developments-have spearheaded both the physical design and actual construction of Waterfall City. Atterbury Property Group, a huge real estate conglomerate that has been at the forefront of developing in excess of 7.5 million square feet $\left(700,000 \mathrm{~m}^{2}\right)$ of prime commercial office properties in high-growth areas across the country, acquired the exclusive property development rights for over 15 million square feet (1.4 million $\mathrm{m}^{2}$ ) of gross rentable area in Waterfall City. ${ }^{15}$ In partnership with Boogertman and Partners Architects, Atterbury Property Group unveiled ambitious

11 Interview with Vos (12 July 2011); Abed Amed, Waterfall City the biggest development in SA, 1 February 2011, promotional materials, available at http://www.century.co.za/newsfeed.html (accessed 10 May 2014).

12 Interviews with Vos (12 July 2011), Parke (11 July 2011) and Steyn (11 July 2011).

13 Interviews with Parke (11 July 2011) and Steyn (11 July 2011); Waterfall Investment Company (n.d.) Live in Johannesburg's largest secure parkland, promotional brochure.

14 Interview with Vos (12 July 2011).

15 Corporate insiders have described Atterbury as a 'highly esteemed property and development company, with an impressive national and international track record of developing, investing and managing blue chip properties' (Waterfall Development, 2011, executive summary, available at http://www.waterfall.co.za/executive.htm, accessed 10 May 2014). 
and as yet unrealized plans to construct an expansive CBD at Waterfall City, a mixeduse commercial precinct that aims to resemble high-density, pedestrian-friendly streetscapes in vogue in world-class cities around the globe. Retail projects planned at Waterfall Business Estate include the remarkable 1.25 million square foot $\left(120,000 \mathrm{~m}^{2}\right)$ Mall of Africa super-regional shopping center in the heart of Waterfall City-the largest single-phase shopping destination in the country. Atterbury has also embarked on the construction of two prime convenience centers, called Waterfall Corner and Waterfall Lifestyle Corner, which will feature tenants such as Woolworths, Checkers and Virgin Active (SA Commercial Prop News, 2012; Engineering News, 2013).

The other major real estate developer in Waterfall City-Century Propertieshas taken charge of the construction of the nearly 1,500 acres (600 hectares) of mixeduse and residential components at Waterfall City, providing everything necessary for a range of lifestyle choices in residential living. At the modest end of the housing spectrum, real estate developers have nearly completed construction of 5,500 units of affordable housing (Cox, 2010). For middle-income homebuyers, Waterfall City plans to produce an estimated 20,000 condominium-style apartments and 860 moderately priced housing units (Fife and Bhengu, 2006). At the upper end of the spectrum, Waterfall City has completed construction of an exclusive 120-unit equestrian estate built around a full-service pavilion replete with game rooms, libraries, restaurants, swimming pool and sauna, and complete equestrian facilities including everything from stables and veterinary rooms to a jumping arena, lunging ring and dressage area (Fife and Bhengu, 2006; Cox, 2010).

Century Property Development, in partnership with Waterfall Investment Company (which holds a 51\% controlling interest), has also undertaken the development of luxury and middle-market retirement communities in Waterfall City. Mimicking Waterfall City's overall comprehensive design, these 'lifestyle villages' have five-star clubhouse facilities that cater to retired residents, providing at their fingertips everything from specialized gym facilities to numerous entertainment and activity centers, business and travel centers, to a posh beauty salon and even a delicatessen that delivers fresh milk and bread. In 2011, the estimated value of these retirement lifestyle villages exceeded R3 billion (or approximately US \$370 million), and more than 1,500 units were either completed or under construction. ${ }^{16}$ These retirement villages strive to blend 'California lifestyle' options as the global phantasmagoric ideal, with blanket-like security (Fife and Bhengu, 2006).

\section{- $\quad$ Privatized urbanism at Waterfall City}

The private nature of Waterfall City is particularly clear when examining the role that one family has played in the development of this megaproject. Waterfall City has been built on property purchased by Moosa Ismail Mia under a real estate holding company called Witwatersrand Estates, Ltd. in 1934, and is still held in a privately managed Mia Family Trust. Members of the extended Mia family have continued to play a large role in the management of Waterfall City (Cox, 2006a; Fife and Bhengu, 2006). ${ }^{17}$ Corporate investment in the Waterfall City project is complex, with interlocking directorships, outside investors, silent partners and complicated partnerships. As part of the negotiations that cobbled together the large-scale property development, the principal owners of Waterfall Investment Company-the Waterfall Islamic Institute, founded and still owned by the Mia Family Trust-agreed to a $22 \%$ shareholding in Atterbury Property Investment Holdings. Besides receiving a generous monthly payment, the Islamic Institute has worked out a financial arrangement that allows it to share in Atterbury's growth (Fife, 2008; EPROP, 2009b). Whether as private investors

16 Waterfall City, Current investments, available at http://www.waterfallinvest.co.za/current-investments.aspx (accessed 10 May 2014).

17 Interview with Vos (12 July 2011) 
or as real estate developers, major property-holding companies include Century Property Developments, Sanlam Properties, Investec Property Group, Growthpoint Properties, Zenprop, Group 5, Netcare and Atterbury Property Group. The pyramidal organization of governance structures reflects the centralization of power in a few hands. As stakeholders, property owners in each of the precincts have the collective authority to contract a private management company that in turn outsources the delivery of services. Control over day-to-day operations has been handed over to an independent, private management company responsible for ensuring the uninterrupted provision of essential services such as electricity, security and access control, infrastructure maintenance, waste management, sanitation and cleaning, refuse removal, landscaping and enforcement of rules and regulations governing the use of space (Fife and Bhengu, 2006; Martin Kramer Engineering, 2006; EPROP, 2009b). ${ }^{18}$ Waterfall Investment Company (WIC) sits atop the pyramid, with four directors-two of whom are from the original Mia family-overseeing the management of the entire enterprise by retaining for itself the right to cancel or veto decision making at the lower precinct level. ${ }^{19}$ Without any competition, guaranteed profits flow from the service providers at the bottom to the real estate holding company at the top.

Two key elements have been essential in getting the Waterfall City project off the ground. First, from the very beginning, the property developers who planned Waterfall City regarded the top-down installation of large-scale, bulk infrastructure as the key to their success. ${ }^{20}$ While the original Cradle City project has been slow to move beyond the planning and design phases that precede construction, Waterfall Investment Company has already laid down arterial roads and precinct streets, installed main water pipes, the sewer system and the basic electricity grids, and constructed the outer walls and entrance gates for each of the separate precincts. Waterfall Investment Company even agreed to take responsibility for rehabilitating woefully inadequate road infrastructure outside the perimeter of Waterfall City around the Allandale interchange and the access roads connecting to the N1 highway in exchange for relaxed zoning regulations (EPROP, 2009b). These massive investments in basic infrastructure networks have enabled both Atterbury and Century to attract private investments in office complexes and housing units. ${ }^{21}$

Secondly, in order to get Waterfall City in motion, Atterbury Property Group and Century Properties negotiated long-term, 99-year leasehold agreements with the Waterfall Islamic Institute. This leasehold agreement is automatically renewed every three years, thereby in effect granting land rights in perpetuity (Cox, 2010). ${ }^{22}$ This arrangement has influenced the overall management of the properties within Waterfall City. Corporate tenants who lease office space in the business estate from Atterbury Property Group as well as residents in Century Property's residential estates are required to abide by a strict set of predetermined rules governing the management of their properties. In the business estate these rules articulate the Property Management Association's responsibility for handling safety and security, access control, cleaning and routine maintenance of all common areas for the business estate. ${ }^{23}$ In the residential estates, some of these codes mimic the formulaic protocols that gated residential communities typically use for regulating the use of communal spaces and establishing various aesthetic guidelines, dictating elements such as the size and style

18 Interviews with Parke (11 July 2011) and Steyn (11 July 2011)

19 Interviews with Vos (12 July 2011) and Parke (11 July 2011).

20 Interviews with van Rhyn (14 June 2012) and Vos (12 July 2011).

21 Interviews with Vos (12 July 2011), Parke (11 July 2011) and Steyn (11 July 2011).

22 Waterfall Development, 2011, Development and land fact sheet, page 2, available at http://www.waterfall.co.za/ downloads.htm (accessed 10 May 2014); interviews with Vos (12 July 2011) and Parke (11 July 2011 ).

23 Waterfall Development, 2011, Development and land fact sheet, page 2, available at http://www.waterfall.co.za/ downloads.htm (accessed 10 May 2014); interview with Vos (12 July 2011). 
of fences, the use of streetscapes and the visible display of signs. ${ }^{24}$ However, in their devotion to Islam, the Mia family has moved these restrictive codes far beyond homeowner association codes that specify things such as acceptable colors for house paint (Fife and Bhengu, 2006) ${ }^{25}$ The Mia Family Trust has used their rights of private ownership to forbid activities inimical to Islam within the boundaries of Waterfall City. While alcoholic beverages are available in restaurants, there is a strict prohibition on the establishment of liquor stores anywhere in Waterfall City. The Waterfall Investment Company has outlawed the establishment of Christian churches or the visible display of Christian crosses anywhere inside the precinct (ibid.). ${ }^{26}$ These religion-based rules and restrictions illustrate the kind of rule making and regulation possible in a private development such as Waterfall City.

Under the sign of the entrepreneurial city, urban management assumes an entirely new meaning. Private management companies have taken command over the administrative machinery of municipal governance, and, in effect, replaced municipal authorities and transformed themselves into a new kind of shadow or surrogate public administration. ${ }^{27}$ The adoption of land-use management systems and comprehensive regulatory regimes (including the strict enforcement of by-laws and building codes) enables these private management companies to retain total and firm control over the character, shape and pace of property development and land use in the entire precinct. ${ }^{28}$

The organization and management of Waterfall City demonstrates the primacy and exercise of private control of urban space in place of municipal management and influence. An independent, privately owned management company has assumed responsibility for overseeing and carrying out functions typically reserved for local municipal agencies. In the modernist conception of an efficiently managed city, the police department is a key municipal agency, charged with responsibility for public safety and law enforcement. In Waterfall City, by contrast, security is firmly in the hands of private companies, further demonstrating the exercise of private control instead of municipal regulation. The corporate owners have subcontracted a private management company to oversee all concerns related to safety and security. Atterbury Property Group has divided the business estate into a mosaic of separate parcels surrounded by walls, gates and barriers that are protected by 24 -hour access controls, mimicking global trends toward 'safer cities through environmental design'. Similarly, Century Property Development has effectively militarized the residential areas by constructing an integrated system of gatehouses, mounted CCTV cameras with cuttingedge Israel-designed thermal technology dispersed around the premises, and mobile armed patrols. ${ }^{29}$ Four-meter-high reinforced concrete walls (topped with an electric fence and mounted with CCTV cameras) surround the various residential estates; these are accessed by fingerprint ID technology and staffed by private security guards, thus providing perimeter protection against unwanted intruders. ${ }^{30}$ High-tech fiber optic cables are concealed within these perimeter walls, alerting security to any 'disturbance' to the wall. This allows security guards to pinpoint the precise location of an attempted break-through and to quickly dispatch armed-response vehicles to survey the scene. ${ }^{31}$ In promotional literature, Century boasts that its 'state-of-the-art security systems' are 'effectively and aesthetically integrated into the resident's lifestyle

Interviews with Vos (12 July 2011) and Steyn (11 July 2011); Waterfall Country Estate Homeowner's Association: conduct rules, available at http://www.century.co.za/waterfallcountryestate/index.html (accessed 10 May 2014). Interview with Vos (12 July 2011). Interview with Vos (12 July 2011). Interviews with Holman ( 8 July 2011) and Reid ( 8 July 2011).

Amari Properties, Cradle City master plan (submitted to the City of Johannesburg Development Planning and Urban Management Department, Development Planning \& Facilitation, 27 June 2008). Interviews with Vos (12 July 2011) and Parke (11 July 2011). Century Property Developments (n.d.) Waterfall Country and Equestrian Estate, promotional brochure. Interview with Steyn (11 July 2011). 
so as to be non-intrusive, yet highly visible to the outside world'.$^{32}$ Furthermore, every residential unit is outfitted with what is known as 'SmartTel technology', enabling residents to monitor CCTV cameras at the gatehouses on their home television screens and, in turn, allowing estate security personnel to communicate via telephone with homeowners. ${ }^{33}$ With such extreme safety measures, the residential estates seem to resemble a military compound.

\section{Lanseria Airport City/Cradle City: aerotropolis-in-the-making}

In 2008, Amari Holdings/Forum Properties, a huge property-holding company with deep financial pockets and international expertise, unveiled an ambitious master plan to build a private, self-contained city situated on approximately 98 million square feet $\left(9\right.$ million $\mathrm{m}^{2}$ ) of low-value agricultural land surrounding the privately owned Lanseria International Airport, located at the far northwest corner of metropolitan Johannesburg (EPROP, 2009a; Fife, 2009). The real estate developers and design professionals involved in this expansive megaproject, which they named Cradle City, claimed that when this new city-within-a-city is complete it will be worth an estimated R35 billion (or US $\$ 4.3$ billion), making it the largest single property development ever earmarked for Gauteng province. Hailed as the first privately planned city in South Africa to be fashioned entirely from scratch, Cradle City promised to be a one-of-akind building project that could take anywhere from 7 to 25 years (or even longer) to complete. ${ }^{34}$ With Lanseria airport as the centerpiece, initial plans for this development consisted of a vibrant mix of residential, commercial, office, retail, hotel, resort, entertainment, warehousing and other elements (EPROP, 2009c). The early vision for Cradle City was to create an unparalleled, world-class, mixed-use precinct that would 'provide the opportunity for people to live, work, play and travel in an integrated environment that embraces new urban design and green building principles' (EPROP, 2009a). ${ }^{35}$

The property developers behind the planned Cradle City development proclaimed that the inspiration for this city-building project is an exciting new urban form called an 'aerotropolis'-novel kind of multifunctional city that has an airport transport hub at its core (EPROP, 2009c). Analogous in shape to the conventional metropolis with its high-density central core surrounded by rings of commuterdependent residential suburbs, the new airport city is to consist of a commercial hub surrounded by aviation-linked business clusters (such as freight forwarding, aircraft maintenance, express couriers and warehousing) and residential developments spread out over a radius of up to approximately 20 miles $(32 \mathrm{~km})$, linked by transportation corridors. The aerotropolis represents a reinvention of contemporary urbanism, where the urban form is structured around the principles of mobility, speed and movement (Kasarda, 2009). ${ }^{36}$

The thinking behind airport cities reflects the exaggerated logic of the entrepôt originally associated with such 'instant cities' as Dubai (Elsheshtawy, 2010). Like other traveling ideas that circulate freely in the global marketplace of consultancies and seem to gain traction overnight (Tait and Jensen, 2007), this model was quickly copied by other airport-centered destinations such as Incheon International Airport (Seoul), Schiphol International Airport (Amsterdam), Suvarnabhumi International Airport (Bangkok) and Chek Lap Kok International Airport (Hong Kong). Airportintegrated urban regions around the world have become key nodal points in global

32 Century Property Developments (n.d.) Waterfall Country and Equestrian Estate, promotional brochure.

33 Century Property Developments (n.d.) Waterfall Country and Estates-Smart Village, promotional brochure.

34 Information for this and the following paragraphs also derived from interviews with van Brakel (8 July 2011 ), Aitken (8 July 2011) and Seward (13 July 2011).

35 Interview with van Brakel (13 July 2011).

36 During a public lecture at O.R. Tambo International Airport, sponsored by the Ekurhuleni Airport Cities World Conference and Exhibition on 14 July 2011, John Kasarda described the 'aerotropolis' in such broad and vacuous terms that the concept itself appeared meaningless and hence analytically useless. Other observers, however, are considerably more nuanced and precise when employing the concept. 
production, distribution and corporate enterprise in the global economy (Kasarda, 2009: 58). These air gateways have become as much destinations in their own right as they are crossroads and places of departure. Much like the railroads in the nineteenth century, airport-centered edge cities function as powerful engines of local economic, attracting aviation-linked businesses such as time-sensitive manufacturing, storage and distribution; destination shopping malls and factory outlets; information technology complexes; office parks; convention centers; trade and wholesale merchandise marts; hotel and entertainment centers and consumer services of all types. In the new aerotropolis, form follows function, with corridor and cluster development, easy accessibility and fast movement reflecting the accelerated demand for connectivity, speed and flexibility that characterize the value-added economies of the post-industrial era. Airport expressway links (aerolanes), complemented by express trains (aerotrains), bring cars, taxis, buses, trucks and rail together with air infrastructure at the commercial core-the airport city. Aviation-linked business clusters and residences radiate from the airport city, forming the airport-integrated urban region (Kasarda, 2009: 56-60; Kasarda and Lindsay, 2011).

Property developers envisioned Lanseria International Airport as the key catalyst for the accelerated development of an air-cargo trans-shipment point in a global network of trade. Innovative plans for the development of Cradle City promised both to enhance the position of the airport as an incubator for economic growth, and to accelerate the urban development goals the City of Johannesburg envisions for the area. While provincial and municipal officials were initially skeptical of the project, they eventually recognized the value of such a large development as the centerpiece of the long-term vision of creating a global city region that would link Johannesburg, Tshwane (Pretoria) and Mogale City (Krugersdorp) in a dynamic world-class megalopolis and thereby solidify the world-class aspirations of the greater Johannesburg metropolitan region (Pillay, 2012). ${ }^{37}$

Strong residential increases in the surrounding areas, the enhancement of existing roads and development of new ones, the convenient location of the airportespecially for travelers from Pretoria, the West Rand and what is known as the "new north' (the far northern suburbs of Johannesburg) - have combined to create a growing demand for the services of Lanseria airport-the second largest international air travel gateway in Gauteng province. Indeed, if Cradle City aimed to stimulate and participate in the fast-paced development at Lanseria, it was just in time. In 2008, the private owners of this once out-of-the-way regional airport began to move forward with its ambitious growth plans. Travelers who have grown weary of the traffic delays and the long lines at Johannesburg International Airport/OR Tambo airport find the quick and casual atmosphere at Lanseria a welcome relief. The airport substantially altered its profile in order to accommodate increased demand. While in the past perhaps as many as $80 \%$ of departing passengers used unscheduled corporate and private flights, the airport owners have been signing up new airline carriers (including British Airways), greatly expanding the number of scheduled commercial flights. In 2008, industry experts forecast that the 300,000 departing passengers using Lanseria airport would escalate to 7 million by 2017. Likewise, it is expected that over the next decade scheduled flights could surge from 1,100 to 4,000 a year. Real estate developers were confident that the growth of freight traffic through Lanseria airport will be the key to spurring the rapid development of Cradle City. The anticipated increase in total freight from 5,000 tons in 2008 to 20,000 tons by the year 2017 is predicted to drive the growth in demand for warehousing, distribution, hotels and related services (Chauke, 2006; EPROP, 2009c; Fife, 2009; Sibali, 2009). Real estate developers envision Lanseria as a major transportation hub, with state-of-the-art air freight inspection services, and 


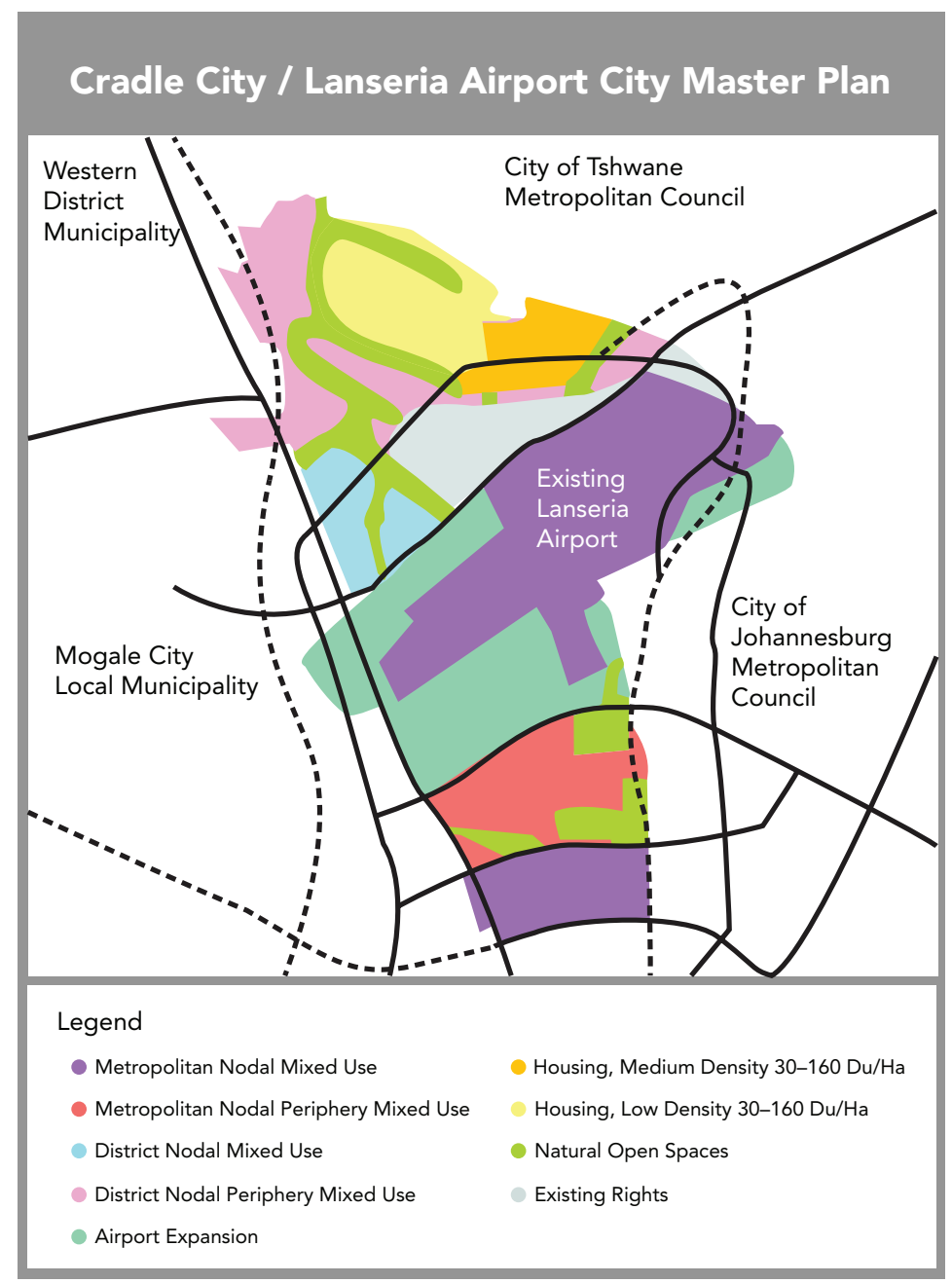

FIGURE 3 Lanseria Airport City/Cradle City urban design plan (map produced on behalf of the authors by Stephanie McClintick)

an airport where business travelers can pass through streamlined customs controls in less than 15 minutes. ${ }^{38}$

- $\quad$ Lanseria Airport City/Cradle City: from stalled pipe dream to phoenix rising?

Initially, the planned development of Cradle City consisted of six phases. The plans for the first phase, called Cradle City Business Park, called for the construction of a 195 acre (38 hectare) site within easy walking or driving distance of the airport terminal. As a planned gateway to the airport, this premium-grade, mixed-use business park includes light industrial, warehousing and storage facilities, retail sites, office space for freight companies and several hotels. The second phase called for a conventional mixed-use area of approximately 440 acres (180 hectares, including medium- and high-density housing, commercial and retail outlets, and a resort and entertainment 
component balanced by public amenities such as parklands and plazas. ${ }^{39}$ At its northern edge, this largely residential area links with the existing upscale low-density housing developments of Blair Athol (with its signature Gary Player golf estate) and Monaghan Farm. Part of this area's attraction is its close proximity to the nearby Cradle of Humankind-a designated World Heritage Site in northwest Johannesburg-and to the numerous surrounding tourism and conservation areas. This northern precinct is called the 'Green Coast' because it enjoys magnificent views of the nearby Magaliesberg mountain range and has exceptional natural features, including both the Crocodile River and the Jukskei River (see Figure 3) (EPROP, 2009a; 2009c).

In the next several phases, property developers planned to create a dynamic 'city center' in the southern precinct of Cradle City, linked seamlessly with the nearby residential components, schools and leisure amenities. Expected to grow incrementally in a series of planned stages, this high-density business core will include a largescale shopping mall along with 20 - to 25 -storey high-rise office buildings, residential apartments and entertainment sites. Based on ideas borrowed from New Urbanism, the developers hope to optimize the mix of uses, facilities and amenities so as to create a vibrant, thriving focal point that acquires a recognizable identity for itself (Daily Sun, 2009; Sibali, 2009). ${ }^{40}$

The property developers behind Cradle City have carved out a specialized niche deliberately designed to position them as stakeholders in the making of the Johannesburg global city-region. They want to build an efficient air transport and service center, capable of handling the ever-expanding volume of freight and airline passenger traffic expected to flow through the greater Johannesburg metropolitan region over the next half century. Eager to get their project under way, Amari Holdings/Forum Properties obtained mixed-use building rights for 26 million square feet $\left(2.5\right.$ million $\left.\mathrm{m}^{2}\right)$ of 'bulk' land (industry jargon for space that is habitable and income-producing) (EPROP, 2009c). To put this figure in perspective, the 122-year-old Johannesburg CBD measures about 23 million square feet $\left(2.1\right.$ million $\left.\mathrm{m}^{2}\right)$. If Cradle City reaches its full development potential, it will be 20 times larger than the upscale, glitzy experiment with New Urbanism in Johannesburg called Melrose Arch (including its recent expansion), three times larger than Sandton's CBD and six times larger than the proposed Waterfall City project. Cradle City's property owners and sales management team at Forum Properties envisioned this future city to include 10.5 million square feet (nearly 1 million $\mathrm{m}^{2}$ ) of residential housing (about 30,000 homes), 7.9 million square feet $\left(730,000 \mathrm{~m}^{2}\right)$ of office space (the equivalent of 30 Johannesburg's Carlton Centre office towers), 2.5 million square feet $\left(230,000 \mathrm{~m}^{2}\right)$ of retail space (five times larger than the Sandton City shopping center) and 3.6 million square feet $\left(335,000 \mathrm{~m}^{2}\right)$ of warehouses and light industrial buildings. Cradle City's design sketches include 682,000 square feet $\left(65,000 \mathrm{~m}^{2}\right)$ set aside for tourism and leisure attraction sites, and nearly 28 million square feet (2.6 million $\mathrm{m}^{2}$ ) reserved for green space and parklands (Fife, 2009; Sibali, 2009) ${ }_{4}^{41}$

Just like the modernist dreamers who looked upon the construction of Brasilia as an extraordinary opportunity to build from scratch without any intermediary steps, the property developers who have envisioned this future city built around Lanseria airport can give free rein to their imagination. The design guidelines for Cradle City promote an ecologically conscious approach to the built form, urban layout and transportation, incorporating renewable materials, water and waste recycling, and efficient energy generation and management. ${ }^{42}$ Enthusiastic promoters of the real estate project proclaimed that 'Cradle City will become a complete destination, with 


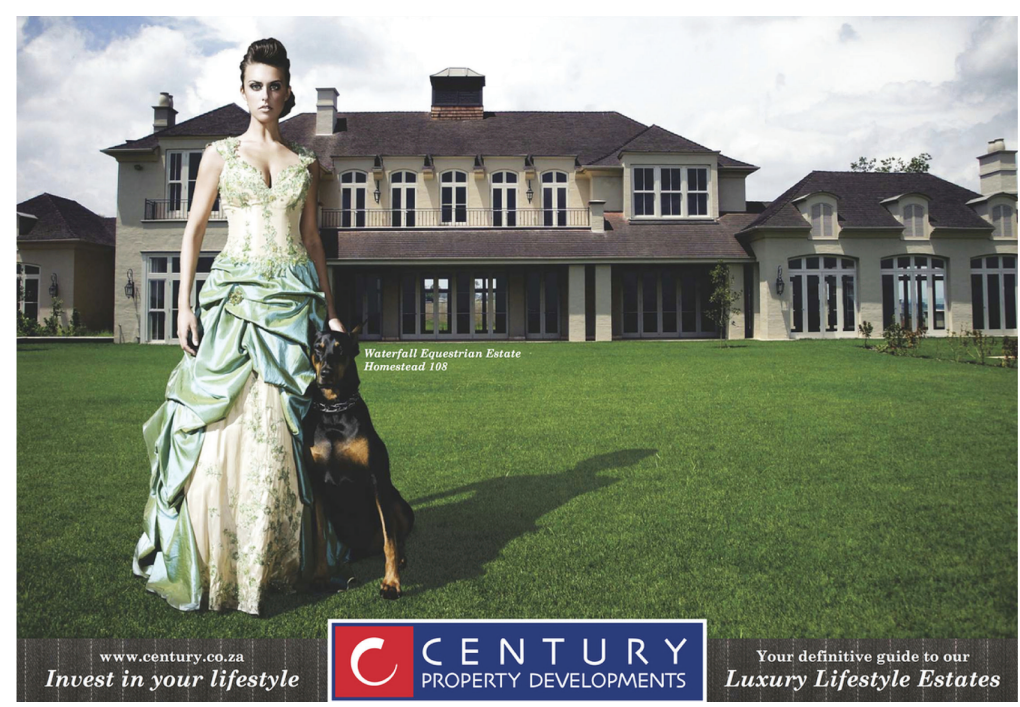

FIGURE 4 Extravagant lifestyle branding for Waterfall City: promotional image for the Waterfall City Equestrian Estate (source: Century Property Developments, n.d., Waterfall Country and Equestrian Estate-The Lifestyle, promotional brochure, page 1)

everything required for quality everyday living [situated] in a vibrant, sustainable environment'. ${ }^{43}$

But fantasy is almost always at odds with reality. Slow property sales brought the Cradle City project to a virtual standstill. Cautious investors did not readily commit to the project, waiting for the completion of roads and installation of bulk infrastructure before considering the purchase of properties. ${ }^{44}$ Skeptical observers suggested that the Lanseria airport site was too far from the existing growth corridor along the main freeway linking Johannesburg and Pretoria to make this megaproject viable. ${ }^{45}$

The establishment of the Lanseria Airport City Development Company (LACDC) in July 2010 gave the stalled Cradle City project a much-needed jump-start. LACDC is a private-investment and property-development consortium consisting of Crosspoint Property Investments, Delta Built Environment Consultants and Lanseria International Airport. At the start, LACDC absorbed the original master plan for the Cradle City project initiated by Amari Holdings/Forum Properties, forged strategic partnerships with the local municipalities (Johannesburg, Mogale City and Tshwane), brought an infusion of fresh capital, introduced a more sophisticated management team and created a broader vision. In addition, LACDC worked out a collaborative arrangement with Forum Properties, established a strategic partnership with a private business park named Lanseria Corporate Estates (covering about 222 acres, or 90 hectares, with a total of 169 industrial stands available for purchase) and engaged with a high-profile town planning consultancy to cobble together the various components of the revamped project. Acting with the official support of the City of Johannesburg, LACDC established a broad-based public-private partnership in July 2012 with the Johannesburg Property Company, the City of Johannesburg Department of Economic Development and the Johannesburg Development Agency (JDA) as part of the statesponsored Lanseria International Airport Economic Development Initiative. In order

43 Sherry Seward, Managing Director of Cradle City Sales quoted in Business Day (Sibali, 2009); interview with Seward (13 July 2011).

44 Interviews with van Brakel (8 July 2011 and 13 July 2011), Aitken (8 July 2011) and Seward (13 July 2011).

45 Interviews with Vos (12 July 2011) and Seward (13 July 2011). 
to encourage large-scale private investments and to accelerate the creation of this fully fledged 'airport city', LACDC has moved toward the creation of 'special zones', which would offer such incentives as tax concessions, more flexible labor laws and relaxed oversight (Booyens, 2012; City Press, 2012).

In November 2012, Lanseria International Airport was sold to a consortium consisting of Harith, a private infrastructure development fund management company; a female-owned black empowerment company called Nozala; and the Government Employee Pension Fund, which is managed by the Public Investment Corporation. Immediately after purchasing the airport facilities, these new investors unveiled a 5 -year plan to upgrade and improve the runway, expand parking facilities, construct a new passenger terminal, and seek new airlines to use the airport. All this has helped Lanseria International Airport solidify its position as the fourth busiest airport in South Africa (Booyens, 2012; Visser, 2012). Some aviation experts argue that Lanseria is not much of a competitor to ACSA, the state-owned operator of nine airports across South Africa. But as the only privately owned airport in South Africa, LAC/Cradle City has remained the centerpiece of a visionary scheme to construct a private aerotropolis in the heart of Gauteng province (City Press, 2012).

\section{Place promotion: the branding of Waterfall City and LAC/Cradle City as lifestyle choices}

At present, Waterfall City and LAC/Cradle City exist as both imaginary places and actual physical locations. The notion of the city as a conglomeration of visual signs is part and parcel of a new urban-image politics that places a great deal of emphasis on outward appearance and performative spectacle (Huyssen, 1997; Klingmann, 2007; Greenberg, 2008). In the lively discourse of place marketing and branding, 'selling the city' depends upon the ability to conjure up comforting images of places that artfully erase inconvenience, hardship and the distasteful aspects of urban living. Advertisers market them as offering new, vibrant, luxurious lifestyles with all the social amenities befitting an up-to-date, hyper-modern city. In order to draw attention to Waterfall City and LAC/Cradle City as inviting places to live and work, real estate developers have stressed in particular the diversity of activities, the heterogeneity of opportunities and the variety of lifestyle options. By implementing their branding strategies, corporate boosters have saturated these new urban enclaves with global images of choice and convenience, leisure and relaxation, and conspicuous consumption (Klingmann, 2007: $3,14,91$ ) (see Figure 4).

What is at stake in projected master-planned and privately owned urban enclaves in Africa such as Waterfall City and LAC/Cradle City is nothing less than the desire to create a sense of uniqueness in urban space, of creating the impression that each particular city is like no other in the world. What is ironic about these city-building projects is that their real estate developers have hired architectural firms and design specialists who have proclaimed emphatically that they have borrowed from generic templates to cobble together urban places that are at once cosmopolitan, global and up to date. Real estate agents and sales personnel have borrowed the popular 'Live, work and play' slogan and attached it to promotional materials advertising Waterfall City and LAC/Cradle City, proclaiming that they are bringing something new to urban Africa. ${ }^{46}$

'Hard branding'-to borrow a term from Graeme Evans (2003: 417)-involves heavy doses of wishful thinking and myth making. Place-marketing strategies deploy ambitious and comprehensive use of imagery that capitalizes on the fashionable tastes of the day. No longer merely an effable enhancement of capital, symbolic capital gains efficacy when it is transformed into a commodity (Easterling, 2007a: 11). The developers of the refurbished LAC/Cradle City have fashioned their own ideology of urban 
transformation, combining the promises of contemporary progressive urbanism with money-driven planning (Varnelis, 2005: 177). Sales managers charged with branding LAC/Cradle City as an innovative place have put the public-relations machine on full throttle by invoking the language of sustainability, greenscapes, energy efficiency, environmental friendliness, ecological soundness, renewable resources and waste recycling to construct a powerful image of an up-to-date experimental city at the forefront of environmental consciousness (EPROP, 2009a), thus wrapping their project in fashionable discourses that are in vogue in contemporary planning circles (van der Merwe, 2009). The symbolic capital that place marketing provides in the form of an originating identity as a genuinely 'green city' lends a carefully designed camouflage of goodwill to the commercially driven intentions of the property developers. By cleverly manipulating these symbols of healthy urbanism, they have painted a glossy picture of a new airport edge city that does not yet exist. Yet they also recognize that actually providing renewable energy sources and creating eco-friendly features makes LAC/ Cradle City more attractive to potential buyers. By cloaking their megaprojects in the language of international best practices, real estate developers and design specialists are able to proclaim that what they are doing is 'as good as anything in the West' ${ }^{47}$

The masterful art of selling-or branding-places has become one of the defining characteristics of the entrepreneurial city (MacLeod, 2002; Klingmann, 2007; Greenberg 2008). In order to highlight its distinctive features, Waterfall City is being promoted as a 'lifestyle choice', a wholesome, family-oriented place that seeks 'to attract people who want to enjoy a superior quality of life by living close to their place of work and to enjoy a wide range of recreation facilities', and its promotional literature boasts that 'family values and wholesome living set the tone'. ${ }^{48}$

Corporate boosters have enveloped Waterfall City in a rhetoric and discourse that blends two key themes as selling points. On the one hand, real estate developers have marketed Waterfall City as a new, forward-looking, hyper-modern city-a clear sign that urban South Africa is catching up with the leading cities of the world in terms of building up-to-date cities. ${ }^{49}$ The real estate developers behind Waterfall City have promised not only that state-of-the-art technology and broadband-based services will be available to property-owning tenants (a first in South Africa), but that they will be provided in an aesthetically pleasing and secure environment. ${ }^{50}$ The stated goal of Waterfall City's corporate developers is to provide a 'comprehensive lifestyle environment geared to become the preferred destination' in the Johannesburg metropole, catering to business executives, wealthy homeowners, discriminating shoppers and tourists. ${ }^{51}$

On the other hand, place promoters have made use of a complex discourse that promotes Waterfall City as both a luxurious and modern lifestyle option for residents and a smart, safe and secure monetary investment for property owners with great upside potential for value enhancement. In other words, buying property is useful, as property provides a place to live and work and offers investment potential by virtue of being a marketable commodity. In its promotion of Waterfall City, Atterbury Property Group suggests that the 'competitive positioning of the Waterfall Development is based on formidable added value features to ensure that it becomes the preferred mixed-use destination in Gauteng of all types of residents, workers, shoppers,

Century Property Developments (n.d.) Waterfall Country and Equestrian Estate-The Lifestyle, promotional brochure.

49 'Our property industry was dislocated from the world property market during the apartheid years and development has lagged behind for 35 years,' claimed Mvelaphanda Properties director Geoff Chait. 'Now it is beginning to catch up as we reconnect with the world' (quoted in Fife and Bhengu, 2006).

50 Century Property Developments (n.d.) Waterfall Country and Estates-Smart Village, promotional brochure.

51 Interview with Vos (12 July 2011). 
tourists and Corporate South Africa'. ${ }^{52}$ In short, the formula for 'selling' Waterfall City is not only to create a useful, liveable urban environment, but also to produce marketable space that generates value for investors. According to Marketing General Manager David Reid, the secret behind the anticipated success of Waterfall City is its 'synergistic mixed-use development framework' and its holistic planning principles that leave nothing to chance (EPROP, 2009b). This company's sole purpose is not merely to create a product, but to create one in which people can and will confidently invest their wealth. Indeed, Waterfall City is seen as reflecting 'growing confidence in the long-term prospects for property investment' (Fife and Bhengu, 2006)..$^{53}$

\section{Johannesburg future city}

In aspiring world-class cities around the globe, municipal planning functions have increasingly been shifted or surrendered to organized business interests, which are concerned less with the spatial integrity and coherence of the metropolitan landscape taken as a whole than with discrete parts located within it (business improvement districts, urban development zones, cultural precincts, themed entertainment spaces). These privatized planning initiatives-or what has been called 'planning through urban projects' (Swyngedouw et al., 2002: 537-48, 563-64)-have normalized entrepreneurial discourses of ownership and stakeholding and lent legitimacy to the private management of city space. Urban planning experts who are paid agents of private capital are responsible not to the public interest but to the bottom line of business profitability.

Both Waterfall City and LAC/Cradle City represent the growing fascination in corporate real estate circles with privately planned cities constructed entirely from scratch. As large-scale profit-oriented urban enclaves, these megaprojects give concrete expression to an ambitious vision, as Gavin Shatkin (2011: 77) has put it, 'for the transformation of the urban experience through the wholesale commodification of the urban fabric'. The developers behind Waterfall City and LAC/Cradle City want to create what amounts to their own private metropolis, a twenty-first-century islandlike enclave, replete with the latest gimmicks and gadgetry, packaged in the rhetoric of sustainability, the sound principles of environmental friendliness, and with the assurance of military-like safety features. These large-scale megaprojects aspire to escape the narrow confines of the largely dependent edge cities that surround Johannesburg, and seek instead to assert their role as central players in the contemporary corporate real estate game of constructing successful global city regions (Bloom, 2006; Pillay, 2006). Just like Songdo City (adjacent to the Incheon International Airport 35 miles west of Seoul), Bonifacio Global City (a master-planned Special Economic Zone located in the heart of Metro Manila) and King Abdullah Economic City (a Special Economic Zone on the Red Sea near Jeddah), these new self-contained cities-within-cities bundle together a full range of business, residential and entertainment programs alongside resort-like recreational activities. Waterfall City and LAC/Cradle City exemplify the trend toward spatial fragmentation of Johannesburg, where the sprawling metropolis has splintered into self-sustaining, secure precincts defined by a kind of laissez-faire, go-it-alone mentality (Fife, 2009).

The (already-under-construction) Waterfall City and the (not-yet-realized) LAC/Cradle City megaprojects represent the inchoate prototype of new specialized assemblages that produce new types of territory, authority and rights that fall outside the reach of existing public institutional frameworks (Sassen, 2008). They epitomize what Lieven de Cauter (2001: 126) has called the 'logic of capsularization', that is,

52 Atterbury Property Development Group (2008) Waterfall City press release, September 2008 (WWW document). URL http://www.atterbury.co.za/Cms_Data/Contents/AtteburyDB/Folders/news-items/ contents/ XX727Z482EVLPAUL/WaterfallCityPressReleaseSept2008.pdf (accessed 10 May 2014). Interview with Seward (13 July 2011). 
spatial enclosures that shelter what is inside from what is feared 'outside'. These future cities-in-the-making are holistic, master-planned enclaves, sprawling catchment areas designed for capturing the circulating global values of private entrepreneurship, luxury living and cosmopolitan consumer culture. These spatial envelopes occupy a discrepant territory between two distinct species of contemporary urbanity. On the one side, these precincts bring together the requisite features-office complexes for work, private homes for residential accommodation and aesthetically-pleasing places for leisure and entertainment-that define what a good city should be. On the other side, these self-enclosed enclaves function like privately managed enterprise zones operating outside the legal jurisdiction of the municipal authority that physically surrounds them (Wong and Chu, 1984; Phillips and Yeh, 1987; 1989; Easterling, 2007a; 2007b; Seshadri, 2012). These new satellite cities conform to what has been called 'privatized urbanism' or the 'entrepreneurial city' (Hall and Hubbard, 1996; 1998).

Waterfall City and LAC/Cradle City signal the unbundling of conventional municipal authority (Easterling, 2005: 2-5), by seeking immunity from public administration and unwanted oversight. With limited financial resources and over-taxed staff, municipal planning agencies in charge of overseeing large-scale megaprojects often relinquish a great deal of what is typically considered public authority to private developers. Real estate developers have learnt that by providing funding and technical expertise in the installation of bulk public infrastructure (such as road upgrading, storm drainage and other physical improvements) they greatly enhance their chances of winning approval for large-scale development projects such as Waterfall City and LAC/ Cradle City. ${ }^{54}$

The evolution of the Johannesburg metropole into a sprawling patchwork of dispersed and inward-looking building typologies-often depicted in the conventional urban studies literature as the unfortunate consequence of unplanned growth responding to market demand-has in fact been the outcome of deliberate choices made by an intersecting phalanx of special interests, including property developers, real estate agents, large-scale banks and lending institutions, building contractors, design specialists and architectural firms. The selection of different kinds of sequestered enclaves is never simply the result of a single-minded, calculated response to the profit motives of real estate capitalists, but is a distinct socio-cultural intervention into the urban social fabric. The spatial design of urban space cannot be reduced to technical exercise judged on aesthetic principles alone, but is a deliberate socio-cultural intervention that seeks to project a particular vision of an imagined future city (Murray, 2011: xxiii, 285). The construction of master-planned enclaves such as Waterfall City and LAC/Cradle City reflect an ideological mindset that favors enclosed space over shared openness, physical separation over civic engagement and privileged exclusivity over tolerant inclusion.

Although these extra-territorial sites are in their early stages of development, they bring together a variety of institutional features that have the potential to profoundly unsettle our conventional normative understandings of the rights and entitlements of citizenship, the expanding role of private entrepreneurship in city building and the diminishing place of public authority in regulating, managing and shaping urban space (Ong, 2006; Sassen, 2007; Sidaway, 2007). Waterfall City and LAC/Cradle City embody a new kind of privatized urbanism, where entrepreneurial modes of urban governance have replaced public administration, where large-scale property owners establish the institutional rules governing the use of urban space, and where unwanted people and undesirable activities are kept at bay. These self-contained megaprojects represent the utopian dreamscapes of the postmodern age, where privileged elites seek to insulate themselves from the harsh realities of impoverishment, 
joblessness and straitened circumstances that exist all around them (Bremner, 1998; 2002b; 2005).

Claire W. Herbert, Department of Sociology, University of Michigan, 500 S. State Street, Ann Arbor, Michigan 48108, USA, clairewh@umich.edu

\section{Martin J. Murray, Taubman College, Program in Urban Planning, Department of Afro-American and African Studies, University of Michigan, Ann Arbor, Michigan 48104, USA, murraymj@umich.edu}

\section{References}

Altshuler, A. and D. Luberoff (2003) Mega-projects: the changing politics of urban public investment. Brookings Institution Press, Washington, DC.

Beauregard, R. (1995) Edge cities: peripheralising the centre. Urban Geography 16.8, 708-21.

Beavon, K.S.O. (1997) Johannesburg: a city and metropolitan area in transformation. In C. Rakodi (ed.), The urban challenge in Africa: growth and management of its large cities, United Nations University Press, Tokyo.

Beavon, K.S.O. (2004) Johannesburg: the making and shaping of the city. University of South Africa Press, Pretoria.

Bezmez, D. (2008) The politics of urban waterfront regeneration: the case of Halíc (the Golden Horn), Istanbul. International Journal of Urban and Regional Research 32.4, 815-40.

Bloom, J. (2006) Paths to success for a 'city region'. Business Day 2 September [WWW document]. URL http://infoweb.newsbank.com.proxy.lib.umich. edu/resources/doc/nb/news/132D6E6328CDB1A8? $p=A W N B$ (accessed 12 January 2011).

Booyens, Y. (2012) Airport to get a new R150m runway. Engineering News 30 March [WWW document]. URL http://www.engineeringnews.co.za/article/ airport-to-get-r150m-runway-2012-03-30 (accessed 6 July 2013).

Borsdorf, A., R. Hidalgo and R. Sánchez (2007) A new model of urban development in Latin America: the gated communities and fenced cities in the metropolitan areas of Santiago de Chile and Valparaíso. Cities 24.5, 365-78.

Bremner, L. (1998) Crime and the emerging landscape of post-apartheid Johannesburg. In H. Judin and I. Vladislavić (eds.), Blank: architecture, apartheid and after, NAi Publishers, Rotterdam.

Bremner, L. (2002a) Living on the edge. Sunday Times Lifestyle 17 February [WWW document]. URL http:// infoweb.newsbank.com.proxy.lib.umich.edu/ resources/doc/nb/news/132F6B6696691750? $\mathrm{p}=\mathrm{AWNB}$ (accessed 12 January 2011).

Bremner, L. (2002b) Closure, simulation, and 'making-do' in the contemporary Johannesburg landscape. In O. Enwezor et al. (ed.), Under siege: four African cities: Freetown, Johannesburg, Kinshasa, Lagos, Documenta 11, platform 4, Hatje Cantz, Ostfildern-Ruit.

Bremner, L. (2005) Remaking Johannesburg. In S. Read, J. Rosemann and J. van Eldijk (eds.), Future city, Routledge, London.

Bullard, R., G. Johnson and A. Torres (2000) Sprawl city: race, politics, and planning in Atlanta. Island Press, Washington, DC

Bunnell, T., D. Goh, C.-K. Lai and C.-W. Pow (2012) Global urban frontiers: Asian cities in theory, practice and imagination. Urban Studies 43.13, 2785-93.

Chauke, A. (2006) Private airport will get a huge upgrade. Sunday Times 26 September [WWW document]. URL http://infoweb.newsbank. com.proxy.lib.umich.edu/resources/doc/nb/ news/132F684C0CCE4648?p=AWNB (accessed 12 January 2011).

Chipkin, C. (2008) Johannesburg transition: architecture and society from 1950. STE Publishers, Johannesburg.
City Press (2012) Lanseria lifts off to next level. 24 November [WWW document]. URL http://www. citypress.co.za/business/lanseria-lifts-off-to-nextlevel-20121124/ (accessed 6 July 2013).

Cox, A. (2006a) R15bn 'city' to link Pretoria and Joburg. The Star 3 May [WWW document]. URL http://www.iol. co.za/news/south-africa/r15bn-city-to-link-pretoriaand-joburg-1.276236\#.VNj8_3azgkQ (accessed 12 January 2011).

Cox, A. (2006b) Shopping centres worth billions in pipeline. Pretoria News 4 July [WWW document]. URL http:// www.goproperty.co.za/15_news_Shopping-centresworth-billions-in-pipeline.html (accessed 12 January 2011).

Cox, A. (2010) Green architecture: a first for SA. Pretoria News 17 November [WWW document]. URL http://www.iolproperty.co.za/roller/news/entry/green architecture_a_first_for (accessed 12 January 2011).

Czeglédy, A. (2003) Villas of the Highveld: a cultural perspective on Johannesburg and its 'northern suburbs'. In R. Tomlinson, R. Beauregard, L. Bremner and X. Mangcu (eds.), Emerging Johannesburg: perspectives on the postapartheid city, Routledge, New York, NY.

Daily Sun (2009) Cradle City is coming soon. 26 February, 3 [WWW document]. URL http://www.keyprojects.co.za/ admin/documents/090226thesun.pdf (accessed 12 January 2011).

Datta, A. (2012) India's ecocity? Environment, urbanisation, and mobility in the making of Lavasa. Environment and Planning C: Government and Policy 30.6, 982-96.

de Cauter, L. (2001) The capsule and the network. Oase: Tijdschrift voor Architectuur 54, 123-32.

Diaz Orueta, F. and S. Fainstein (2008) The new megaprojects: genesis and impacts. International Journal of Urban and Regional Research 32.4, 759-67.

Dick, H. and P. Rimmer (1998) Beyond the third world city: the new urban geography of Southeast Asia. Urban Studies 35.12, 2303-21.

Dirsuweit, T. and F. Schattauer (2004) Fortresses of desire: Melrose Arch and the emergence of urban tourist spectacles. GeoJournal 60.3, 239-47.

Doucet, B. (2013) Variations of the entrepreneurial city: goals, roles and visions in Rotterdam's Kop van Zuide and the Glasgow Harbour megaprojects. International Journal of Urban and Regional Research 37.6, 2035-51.

Douglass, M. (2010) Globalization, mega-projects, and the environment: urban form and water in Jakarta. Environment and Urbanization Asia 1.1, 45-65.

Douglass, M. and L. Huang (2007) Globalizing the city in Southeast Asia: utopia on the urban edge-the case of Phu My Hung, Saigon. International Journal of AsiaPacific Studies 3.2, 1-42.

Dunham-Jones, E. (2000) New Urbanism as a counterproject to Post-Industrialism. Places 3.2, 6-31.

Easterling, K. (2005) Enduring innocence: global architecture and its political masquerades. MIT Press, Cambridge, MA

Easterling, K. (2007a) Extrastatecraft. Perspecta 39, 4-16.

Easterling, K. (2007b) The zone. In C. de Baan, J. Declerk and V. Patteeuw (eds.), Visionary power: producing the contemporary city, NAi Publishers, Rotterdam.

Elsheshtawy, Y. (2010) Dubai: behind an urban spectacle. Routledge, London and New York, NY. 
Engineering News (2013) Waterfall Business Estate is positioned to be one of SA's most successful nodes, 6 November [WWW document]. URL http:/ www. engineeringnews.co.za/html (accessed 10 May 2014).

EPROP Commercial Marketplace (2009a) Airport-based Cradle City aims to be Gauteng's green city of the future, 18 February [WWW document]. URL http:/www. eprop.co.za/html (accessed 10 May 2014).

EPROP Commercial Marketplace (2009b) City within a city. 26 August [WWW document]. URL http:/www.eprop. co.za/html (accessed 10 May 2014).

EPROP Commercial Property Marketplace (2009c) Cradle City 'aerotropolis' to complement area planning objectives. 11 July [WWW document]. URL http:/www. eprop.co.za/html (accessed 10 May 2014).

Evans, G. (2003) Hard branding the cultural city-from Prado to Prada. International Journal of Urban and Regional Research 27.2, 417-40.

Fainstein, S. (2008) Mega-projects in New York, London and Amsterdam. International Journal of Urban and Regional Research 32.4, 768-85.

Fife, I. (2008) Property tycoon's R25bn coup ... and how he did it. Financial Mail 5 September, 34-41.

Fife, I. (2009) Birth of a private city. Financial Mail 20 March [WWW document]. URL http://www.eprop.co.za/ commercial-property-news/item/10565-Birth-of-aprivate-city.html (accessed 12 January 2011).

Fife, I. and X. Bhengu (2006) Land of promise. Financial Mail 2 February [WWW document]. URL http://www.eprop. co.za/commercial-property-news/item/6517-Land-ofpromise.html (accessed 12 January 2011).

Fishman, R. (1987) Bourgeois utopias: the rise and fall of suburbia. Basic Books, New York, NY.

Fishman, R. (2008) New Urbanism in the age of re-urbanism. In T. Haas (ed.), New Urbanism and beyond: designing cities for the future, Rizzoli, New York, NY.

Garreau, J. (1991) Edge city: life on the new frontier. Doubleday Press, New York, NY.

Goldberger, P. (1996) The rise of the private city. In J. Vitullo-Martin (ed.), Breaking away: the future of cities, Twentieth Century Fund, New York, NY.

Gordon, P. and H. Richardson (1996) Beyond polycentricity: the dispersed metropolis, Los Angeles, 1970-1990. Journal of the American Planning Association 62.3, 289-95.

Graham, S. and S. Marvin (2001) Splintering urbanism: networked infrastructures, technological mobilities, and the urban condition. Routledge, New York, NY.

Greenberg, M. (2008) Branding New York: how a city in crisis was sold to the world. Routledge, New York, NY.

Hall, T. and P. Hubbard (1996) The entrepreneurial city: new urban politics, new urban geography? Progress in Human Geography 20.2,153-74.

Hall, T. and P. Hubbard (1998) The entrepreneurial city: geographies of politics, regime and representation. John Wiley \& Sons, Chichester.

Hall, P. and K. Pain (2006) The polycentric metropolis: learning from mega-city regions in Europe. Earthscan, London.

Hansen, H. and L. Winther (2007) The spaces of urban economic geographies: industrial transformation in the outer city of Copenhagen. Geografisk Tidsskrift, Danish Journal of Geography 107.2, 45-58.

Harvey, D. (1989) From managerialism to entrepreneurialism: the transformation of urban governance in late capitalism. Geografiska Annaler 71.B, 3-17.

Hogan, T., T. Bunnell, C.-P. Pow, E. Permanasari and S. Morshidi (2012) Asian urbanisms and the privatization of cities. Cities 29.1, 59-63.

Huyssen, A. (1997) The voids of Berlin. Critical Inquiry 24.1, 57-81.

Jessop, B. (1997) The entrepreneurial city: re-imagining localities, redesigning economic governance, or restructuring capital? In J. Jewson and S. MacGregor (eds.), Transforming cities: contested governance and new spatial divisions, Routledge, London.

Kanna, A. (2011) Dubai, the city as corporation. University of Minnesota Press, Minneapolis, MN.
Kasarda, J. (2009) Airport cities. Urban Land 68.4, 56-60.

Kasarda, J. and G. Lindsay (2011) Aerotropolis: the way we'll live next. Allen Lane, London.

Kim, C. (2010) Place promotion and symbolic characterization of New Songdo City, South Korea. Cities 27.1, 13-19.

Klingmann, A. (2007) Brandscapes: architecture and the experience economy. MIT Press, Cambridge, MA.

Kokx, A. (2011) Partnerships in urban restructuring: building long-term relationships or pragmatic managerial tool? The Dutch experience. International Journal of Urban and Regional Research $35.5,1026-47$

Lang, E. (2003) Edgeless cities: exploring the elusive metropolis. Brookings Institution Press, Washington, DC.

Lang, R. and J. Lefurgy (2007) Boomburgs: the rise of America's accidental cities. Brookings Institution Press, Washington, DC.

Lehrer, U. and J. Laidley (2008) Old mega-projects newly packaged? Waterfront redevelopment in Toronto. International Journal of Urban and Regional Research 32.4, 786-803

Lipman, A. and H. Harris (1999) Fortress Johannesburg. Environment and Planning B: Planning and Design 26.5, 727-40.

Mabin, A. (2007) Johannesburg: (South) Africa's aspirant global city. In K. Segbers (ed.), The making of global city regions: Johannesburg, Mumbai/Bombay, São Paulo, and Shanghai, Johns Hopkins University Press, Baltimore, MD

MacLeod, G. (2002) From urban entrepreneurialism to a 'revanchist city'? On the spatial injustices of Glasgow's renaissance. Antipode 34.3, 602-23.

Martin Kramer Engineering (2006) New development for Gauteng. 21 June [WWW document]. URL http://www. waterfallinfo.co.za/news.php?item.18.8 (accessed 10 May 2014).

Murphy, P. and T. Hogan (2012) Discordant order: Manila's neo-patrimonial urbanism. Thesis Eleven $112.1,10-34$.

Murray, M.J. (2008) The city in fragments: kaleidoscopic Johannesburg after apartheid. In G. Prakash and K. Kruse (eds.), The spaces of the modern city: imaginaries, politics, and everyday life, Princeton University Press, Princeton, NJ.

Murray, M.J. (2011) City of extremes: the spatial politics of Johannesburg. Duke University Press, Durham, NC.

Murray, M.J. (2013) The quandary of post-public space: New Urbanism, Melrose Arch, and the rebuilding of Johannesburg after apartheid. Journal of Urban Design 18.1, 119-44.

Ong, A. (2006) Neoliberalism as exception: mutations in citizenship and sovereignty. Duke University Press, Durham, NC.

Paling, W. (2012) Planning a future for Phnom Penh: mega projects, aid dependence and disjointed governance. Urban Studies 49.13, 2889-912.

Phillips, D.R. and A. Yeh (1987) The provision of housing and social services in China's Special Economic Zones. Environment and Planning C: Government and Policy 5.4, 447-68.

Phillips, D.R. and A. Yeh (1989) Special Economic Zones. In D. Goodman (ed.), China's regional development, Routledge, London.

Pillay, U. (2006) SA's global city region of the future. Business Day 11 July [WWW document]. URL http:// infoweb.newsbank.com.proxy.lib.umich.edu/ resources/doc/nb/news/132D6E7356E0B080? $\mathrm{p}=$ AWNB (accessed 12 January 2011).

Pírez, P. (2002) Buenos Aires: fragmentation and privatization of the metropolitan city. Environment and Urbanization 14.1, 145-58.

Rogerson, C. (2003) Local economic development in Midrand, South Africa's ecocity. Urban Forum 14.2/3, 201-22.

SA Commercial Prop News (2012) Central Park at Waterfall Business Estate set to become an icon of twenty-firstcentury quality urban living. 23 July [WWW document]. 
URL http://www.sacommercialpropnews.co.za (accessed 10 May 2014).

Sassen, S. (2007) Toward a multiplication of specialized assemblages of territory, authority and rights. Parallax 13.1, 87-94.

Sassen, S. (2008) Neither global nor national: novel assemblages of territory, authority and rights. Ethics and Global Politics 1.12, 61-79.

Seshadri, T. (2012) An analysis of the feasibility of private land assembly for Special Economic Zones in India. Urban Studies 49.10, 2285-300.

Shatkin, G. (2008) The city and the bottom line: urban megaprojects and the privatization of planning in Southeast Asia. Environment and Planning A 40.2, 383-401.

Shatkin, G. (2011) Planning privatopolis: representation and contestation in the development of urban integrated mega-projects. In A. Roy and A. Ong (eds.), Worlding cities: Asian experiments and the art of being global, Wiley Blackwell, New York, NY.

Sibali, L. (2009) Take-off for Lanseria's new cradle city. Business Day (Johannesburg, South Africa) 25 February [WWW document]. URL http://infoweb. newsbank.com.proxy.lib.umich.edu/resources/doc/nb/ news/132D6BC985B866B8?p=AWNB (accessed 12 January 2011).

Sidaway, J. (2007) Enclave space: a new metageography of development? Area 39.3, 331-39.

Soja, E. (1992) Inside exopolis: scenes from Orange County. In M. Sorkin (ed.), Variations on a theme park, Hill and Wang, New York, NY.

Soja, E. (1996) Los Angeles, 1965-1992: from crisisgenerated restructuring to restructuring-generated crisis. In A. Scott and E. Soja (eds.), The city: Los Angeles and urban theory at the end of the twentieth century, University of California Press, Berkeley, CA.

Soja, E. (2000) Postmetropolis: critical studies of cities and regions. Blackwell, Malden, $\mathrm{MA}$.

Sudjic, D. (1993) The 100 mile city. Flamingo, London.
Swyngedouw, E., F. Moulaert and A. Rodriguez (2002) Neoliberal urbanization in Europe: large-scale urban development projects and the new urban policy. Antipode 34.3, 547-48.

Tait, M. and O. Jensen (2007) Traveling ideas, power, and place: the case of urban villages and business improvement districts. International Planning Studies 11.2, 107-27.

Taşan-Kok, T. (2010) Entrepreneurial governance: challenges of large-scale property-led urban regeneration projects. Tijdschrift voor Economische en $\approx$ Sociale Geografie 101.2, 126-50.

Teaford, J. (1997) Post-suburbia: government and politics in the edge cities. Johns Hopkins University Press, Baltimore, MD.

Thompson, C. (2013) Master-planned estates: privatization, socio-spatial polarization and community. Geography Compass 7.1, 85-93.

van der Merwe, C. (2009) 'Green city' master plan approved by Gauteng councils. Engineering News 26 June [WWW document]. URL http://www.engineeringnews. co.za/article/green-building-platform-cradle-citymasterplan-approved-2009-06-26 (accessed 12 January 2011).

Varnelis, K. (2005) Los Angeles: cluster city. In S. Read, J. Rosemann and J. van Eldijk (eds.), Future city, Spon Press, New York, NY.

Visser, A. (2012) Lanseria buy 'will support growth of aerotropolis'. Business Day 19 November [WWW document]. URL http://infoweb.newsbank. com.proxy.lib.umich.edu/resources/doc/nb/ news/142AA997F5F9BFC0?p=AWNB (accessed 6 July 2013).

Ward, K. (2003) Entrepreneurial urbanism, state restructuring and civilising 'new' East Manchester. Area 35.2, 116-27.

Wong, K.-Y. and D.K.Y. Chu (1984) Export Processing Zones and Special Economic Zones as generators of economic development: the Asian experience. Geografiska Annaler B 66.1, 1-16. 


\section{Appendix}

Interviews were conducted with the following persons:

Ian Aitken, Director, Key Projects/Development and Project Manager, Cradle City (8 July 2011)

Ashley Holman, Urban Genesis Management, Rosebank (8 July 2011)

Sue Parke, Atterbury Property Developments, Bryanston (11 July 2011)

Kobus Potgieter, Specialist, Development Planning and Facilitation, City of Johannesburg, Department of Development Planning and Urban Management, Metropolitan Centre, Braamfontein (26 June 2012)

Graeme Reid, Urban Genesis Management, Rosebank (8 July 2011)

Werner van Rhyn, Chief Executive Officer (CEO), Waterfall Investment Company, Woodmead North Office Park, Jukskei View (14 June 2012)

Sherry Seward, Managing Director, Cradle City Sales, Amari Land Group (13 July 2011)

Nkateko Shipalana, Specialist, Development Planning and Facilitation, City of Johannesburg, Department of Development Planning and Urban Management, Metropolitan Centre, Braamfontein (26 June 2012)

Irving Steyn, Project Manager, Atterbury Property Developments, Waterfall City (11 July 2011)

Theuns Van Brakel, Director, Van Brakel Professional Planning and Property Services, Cradle City (8 and 13 July 2011)

Willie Vos, Waterfall Investment Company, Woodmead North Office Park, Jukskei View (12 July 2011) 